\title{
O meu traço brinca com o seu: experiências estéticas, interações e desenhos na Educação Infantil
}

\author{
My trace plays with yours: aesthetic experiences, interactions and \\ drawings in Early Childhood Education
}

\author{
Mi trazo juega con el tuyo: experiencias estéticas, interacciones y \\ dibujos en la Educación Infantil
}

\author{
Gilvânia Maurício Dias de Pontes ${ }^{\prime}$ \\ https://orcid.org/0000-000I-9584-5409 \\ Natália Medeiros de Oliveira² \\ https://orcid.org/0000-0002-2167-8238
}

Resumo: $\mathrm{O}$ artigo trata do projeto Desenho em gestos brincantes que propôs a um grupo de crianças de 3 a 4 anos, em uma escola pública, experiências de desenhar, considerando a dimensão estética e a observação do processo expressivo como organizadores da relação entre crianças e o repertório cultural da arte. Tal projeto é parte de uma pesquisa sobre práticas docentes com as linguagens das artes visuais na Educação Infantil. $O$ recorte tem como objetivo apresentar relações entre abordagens sobre desenho e as práticas pedagógicas. Referencia-se na relação entre o desenho, como gesto pessoal e cultivado, e a mediação do professor, fundamentado por autores como Barbosa (2010), lavelberg (2006; 20I3), Pillar (1996;20I2), Dewey (2010), Merleau-Ponty (1999) entre outros. Evidenciou-se que as crianças são protagonistas no desenvolvimento de sua expressão na linguagem do desenho e que os professores podem ser parceiros desse processo.

Palavras-chave: Educação Infantil. Artes Visuais. Desenho.

Abstract: This paper elucidates the project Drawing in playful gestures, in which experiences of drawing were proposed to a group of children aged from 3 to 4 years old in a public school, considering the aesthetic dimension and the observation of the expressive process as organizers of the relationship between children and the cultural repertoire of art. This project is part of a research on teaching practices with the languages of the visual arts in Early Childhood Education. The purpose of the work is to present relations between approaches to drawing and pedagogical practices. It refers to the relationship between drawing, as a personal and cultivated gesture, and the

\footnotetext{
' Doutora em Educação pela UFRGS. Professora da Universidade Federal do Rio Grande do Norte, lotada no Núcleo de Educação da Infância, Colégio de Aplicação, vinculado ao Centro de Educação da UFRN. Coordenadora do Grupo de Pesquisa Arte e Infância (UFRN). E-mail: gilpontes56@gmail.com

${ }^{2}$ Mestranda em Educação pela UFRN. Graduada em Pedagogia e Comunicação. Estudante do Programa de PósGraduação em Educação da UFRN. Membro do Grupo de Pesquisa Arte e Infância (UFRN). E-mail: natalia@nei.ufrn.br
}

Olhar de professor, Ponta Grossa, v. 24, p. I-25, e-1765I.074, 202 I.

Disponível em <https://revistas2.uepg.br/index.php/olhardeprofessor> 
mediation of the teacher, based on authors such as Barbosa (2010), lavelberg (2006; 20I3), Pillar (1996; 20I2), Dewey (2010), Merleau-Ponty (1999) among others. It was evident that children were protagonists in the development of their expression in the language of drawing and that teachers might be partners in this process. Keywords: Early Childhood Education. Visual arts. Drawing.

Resumen: El artículo aborda el proyecto Dibujar en gestos lúdicos que propuso a un grupo de niños de 3 a 4 años, en una escuela pública, experiencias de dibujo, considerando a la dimensión estética y la observación del proceso expresivo como organizadores de la relación. entre los niños y el repertorio cultural del arte. El proyecto se enmarca en una investigación sobre las prácticas docentes con los lenguajes de las artes visuales en la Educación Infantil. El recorte se propone presentar las relaciones entre los enfoques sobre el dibujo y las prácticas pedagógicas, y se apoya en la relación entre el dibujo, como gesto personal y cultivado, y la mediación del docente, a partir de autores como Barbosa (20I0), lavelberg (2006; 20I3), Pillar (1996; 20I2), Dewey (20I0), MerleauPonty (1999) entre otros. Se demuestra que los niños son protagonistas en el desarrollo de su expresión en el lenguaje del dibujo y que los docentes pueden ser socios en este proceso.

Palabras-clave: Educación Infantil. Artes visuales. Dibujo.

\section{Introdução}

O desenho está presente nas práticas docentes de professores de inúmeras maneiras e a ele é atribuído os mais variados significados. $O$ projeto Desenho em gestos brincantes teve como objetivo a reflexão sobre a proposição de experiências de desenhar para crianças pequenas, em contexto de uma escola de Educação Infantil. Para isso, foi preciso investigar os significados do desenho na infância e na arte, e estabelecer relação com a construção do fazer docente. $O$ projeto está vinculado a uma pesquisa cujo foco é a análise de práticas docentes em artes visuais na Educação Infantil, visando a identificação de organizadores que podem nortear o trabalho com as linguagens artísticas na Educação Infantil. Os organizadores dizem respeito a alguns princípios que pode orientar a intencionalidade da mediação do professor. $O$ projeto foi realizado com aportes de pesquisa-intervenção, em 10 encontros nos quais foram propostas experiências com desenho para um grupo de 24 crianças de 3 a 4 anos.

Como referencial para organização da intervenção optou-se por estudos sobre experiência estética em Dewey (2010) e Merleau-Ponty (1999); abordagens da arte/educação em Barbosa (2010) abordagem do desenho expandido, como manifestação de arte contemporânea (DERDIK, 2007; 2010; 2018) e pesquisas sobre o desenvolvimento da linguagem do desenho na infância em Pillar (I996; 20I2) e lavelberg (2006; 20I3), entre outros textos.

A construção do percurso das práticas pedagógicas teve como lastro alguns questionamentos: a que nos referimos quando falamos sobre artes visuais na Educação Infantil? Quais são os significantes que acionamos para refletir sobre experiências estéticas com crianças? Como podemos estabelecer interfaces entre artes visuais, experiências estéticas, Educação Infantil e a linguagem do desenho? Essas questões foram alguns dos disparadores para o planejamento do projeto Desenho em gestos brincantes, e para a construção deste artigo.

O processo de construção das práticas priorizou a leitura de imagens, do cotidiano e da arte para propor às crianças o desafio da criação de seus próprios desenhos. Esse processo foi marcado 
pela escuta atenta dos adultos aos gestos e falas das crianças, como forma de garantir que a participação delas se tornasse o principal fundamento na organização da mediação docente.

Observou-se a "mediação docente" como ato de aproximar as crianças do repertório cultural de saberes/fazeres da linguagem do desenho. Mediação que está investida da intencionalidade educativa, e como tal requer que se observe as várias dimensões de interação que podem estar presentes na relação entre crianças / adultos / imagens. Esse olhar sobre as interações possibilita ao docente ser propositivo ao lançar desafios às crianças e, ao mesmo tempo, observar/escutar o que os gestos e falas das crianças colocam como significativo na vivência das experiências. $O$ protagonismo das crianças, presenciado na leitura e produção de imagens, foi o balizador que guiou a organização das situações de aprendizagem. Dessa maneira, a construção do ato educativo tornou-se um processo criativo pautado pelo diálogo entre adultos, crianças e imagens - voltado para investigação dos saberes/fazeres da linguagem do desenho. Tal diálogo foi estabelecido tanto no que diz respeito a produtos, quanto a processos de produção de imagens. Isto significou nos debruçarmos sobre a leitura de imagens da arte e imagens produzidas pelas crianças, e sobre os processos criativos dos artistas e das crianças. Ressaltase que atuação das crianças como leitoras e produtoras de imagens se deu a partir de suas experiências e possibilidades expressivas, em interação com os repertórios culturais.

\section{Artes Visuais na Educação Infantil: experiências estéticas/educativas}

Tratar de práticas docentes na educação, seja lá qual for a especificidade da discussão, não é possível sem pensar em interfaces. As práticas são constituídas em atos de interação contextualizados. São processos e, ao mesmo tempo, produtos do diálogo entre sujeitos que produzem sentido e se produzem com sujeitos na imersão formativa das práticas. Assim, há sempre dimensões a se considerar na produção e na escrita sobre as práticas. Adultos - crianças - imagens - desenhos - escola, essa foi uma das camadas que desafiaram o nosso olhar. Políticas públicas para Educação Infantil - documentos oficiais em relação à dimensão estética e artística do trabalho do professor de Educação Infantil, foi mais uma camada a decupar no intento de refletir sobre a linguagem do desenho na educação de crianças. Desenho - arte - ensino de arte na infância, mais elementos para o desafio da organização e reflexão sobre as práticas pedagógicas em linguagens visuais na Educação Infantil.

As Diretrizes Curriculares para Educação Infantil - DCNEI (BRASIL, 2010) consideram as características específicas da infância para indicar elementos para constituição identitária das instituições de Educação Infantil. Neste documento, a Educação Infantil é caracterizada como primeira etapa da educação básica, que deve ser ofertada às crianças de 0 a 5 anos em espaços institucionais de caráter educacional, cuja proposta pedagógica deve observar princípios políticos, éticos e estéticos. No que concerne aos princípios estéticos, o documento afirma a relevância da valorização da 
O meu traço brinca com o seu: experiências estéticas, interações e desenhos na Educação Infantil

sensibilidade, da ludicidade, da criatividade e da liberdade de expressão nas diferentes manifestações artístico e culturais (BRASIL, 2010, p. 16). Assim, nas DCNEl é assumida uma concepção ampla de estética, que extrapola o campo das artes e adentra às práticas cotidianas, pautada pela sensibilidade e liberdade de expressão em interface com a dimensão lúdica e criativa. Tais princípios e interfaces também aparecem quando da referência aos eixos de produção das práticas - as interações e a brincadeira. Tais eixos são basilares para pensar as experiências que se faz necessário possibilitar quando do atendimento às crianças em espaços institucionais. Identificamos, na DCNEI, a preocupação com a estética e com a interação das crianças com as artes, quando afirma que as experiências vivenciadas pelas crianças podem provocar movimentos que:

Favoreçam a imersão das crianças nas diferentes linguagens e o progressivo domínio por elas de vários gêneros e formas de expressão: gestual, verbal, plástica, dramática e musical.

$[\ldots]$

Possibilitem vivências éticas e estéticas com outras crianças e grupos culturais que alarguem seus padrões de referência e de identidade no diálogo e conhecimento da diversidade.

$[\ldots]$

Promovam o relacionamento e a interação das crianças com diversificadas manifestações da música, artes plásticas, dança, teatro, poesia e literatura (BRASIL, 2010, p. 25-26).

Nas DCNEl a definição de currículo parte do pressuposto de que para garantir o desenvolvimento integral das crianças, nas práticas pedagógicas, se faz necessário articular experiências e saberes das crianças com o repertório do patrimônio cultural. Essa concepção de currículo, que valoriza as experiências cotidianas das crianças como fundamentais na organização do fazer docente, é reafirmado na BNCC - Base Nacional Comum Curricular (BRASIL, 2017). Dessa forma, a BNCC foi constituída observando os princípios de organização da proposta curricular, como colocados pelas DCNEI, assim como o significado de estética continua a ter uma abrangência para além das artes, mas sem excluí-las. O documento aponta para uma organização da Educação Infantil, diversa da organização do Ensino Fundamental, na qual a criança é o centro da organização das práticas, as experiências a serem vivenciadas devem se pautar pela garantia de direitos de aprendizagem e desenvolvimento: conviver, brincar, participar, explorar, expressar e conhecer-se. No documento há a orientação para que a organização do trabalho educativo com criança observe campos de experiência, nos quais estão indicadas experiências fundamentais ao desenvolvimento e aprendizagem das crianças. A BNCC pressupõe que na Educação Infantil o conhecimento vem com a experiência e que cada criança vivenciará e significará a experiência de forma particular, por isso é fundamental que o professor esteja atento às necessidades e interesses das crianças para que a experiência seja educativa.

Olhar de professor, Ponta Grossa, v. 24, p. I-25, e- I756I.074, 202 I.

Disponível em <https://revistas2.uepg.br/index.php/olhardeprofessor> 
O campo de experiência Traços, Sons, Cores e Formas traz o destaque às linguagens visuais sugerindo a participação das crianças, de forma investigativa e produtiva, em situações que envolvam desenho, pintura, modelagem, colagem, gravura, fotografia, entre outras linguagens.

A organização do projeto Desenhos em gestos brincantes observa como um dos princípios a concepção de experiência estética como experiência sensível/inteligível, que se produz no encontro do sujeito com os formantes estéticos dispostos em seu entorno - cor, tamanho, disposição espacial, cheiro, textura (PONTES; PILLAR, 2018). Esse encontro com o mundo se dá por estesia, isto é, pelo encantamento que mobiliza para conexão entre corpos - sujeito e objeto. O filósofo Merleau-Ponty (1999) afirma que somos carne do mundo, nossa percepção é encarnada. Assim, a forma como o sujeito se deixa afetar pela experiência é corporal e estésico. O corpo, em deslumbramento, é desafiado para entrar em conjunção com o objeto que lhe toma a atenção. Nesse processo de perceber o outro, os sentidos são acionados com um sistema que se mobiliza para apreender o mundo. $O$ corpo sensível produz sentido no encontro com o outro como modo de existir no mundo. $\mathrm{Na}$ organização das práticas do projeto Desenho em gestos brincantes, ao optar pela observação do componente estésico, partimos do princípio de que o encontro das crianças com objetos e imagens, se dá pelos canais sensoriais por meio dos quais vivenciam e significam o acontecimento estético.

Assim como em Merleau-Ponty (1999), também em Dewey (2010), encontramos aportes para continuar afirmando que a relação estética possibilita a interação do sujeito com e no mundo. Para esse autor a experiência estética faz parte da vida cotidiana e extrapola o campo de abrangência da arte. $O$ sujeito atua para produção de composições rotineiras, como por exemplo arrumar uma mesa ou organizar um jardim, enquanto atua também aprecia o produto de sua atuação. $\mathrm{Na}$ experiência estética há interação entre as ações de ver e fazer, o que nos remete à necessidade de considerar tanto o processo quanto $\circ$ produto da ação humana na interconexão entre meios e fins. Dewey investiga a relação de causa e efeito na produção artística, que é considerada sob a ótica do produtor e do apreciador. Ele se debruça sobre o movimento de construção e de apreciação da arte, explicitando a inserção da expressão e da emoção na experiência estética. Esse autor considera o corpo que percebe, e se emociona, como produtor de sentido. A emoção, própria da interação de cada sujeito da experiência, colore a experiência e a torna singular. O corpo todo é afetado quando protagoniza uma experiência. A esse respeito, Dewey afirma que, "o ato de percepção procede por ondas que se estendem por todo o organismo. Assim, não existe na percepção um ver ou ouvir acrescido de emoção. O objeto ou cena percebido é inteiramente perpassado pela emoção" (DEWEY, 2010, p. 135).

Durante a construção da intervenção com as crianças a reflexão sobre o ver/fazer e sobre o lugar que a criança assume neste processo nos instigou à análise e organização de proposições de 
vivências de desenho que se constituíssem como experiência estética e educativa. Para Dewey a experiência educativa é caracterizada por um continuum em que toda ação praticada e/ou sofrida afeta a qualidade das experiências futuras; isso porque gera hábitos e atitudes que estarão presentes na atuação do sujeito em experiências subsequentes. Assim, na organização de práticas pedagógicas, com a intenção de provocar experiências educativas, se faz necessário atentar para a continuidade da experiência. A percepção da mobilização do corpo das crianças, em interações provocadas pelos desafios lançados por cada experiência, é fundamental no planejamento dos percursos de ação do professor. Isto significa, sobretudo, observar como cada criança atua e sofre a experiência, e como a colore com a expressão singular de sua emoção.

Outro referencial importante na organização e desenvolvimento do projeto de desenho com as crianças foi a Abordagem Triangular (BARBOSA, 2010). Tal abordagem se constituiu como uma das tendências contemporânea para ensino de artes visuais, visto que observa a relação entre o ver e o fazer arte, como fundamentais aos processos educativos de significação e criação de imagens. A Abordagem Triangular foi sistematizada no Brasil, na década de 1980, por Ana Mae Barbosa, propondo as ações de ler, contextualizar, fazer como formas de aproximação às produções da arte. Essa abordagem vem sendo atualizada por sua autora, levando em consideração as ponderações de pesquisadores e professores quando contextualizam essa proposta na relação com práticas pedagógicas. Na revisão da Abordagem Triangular, publicada para $8^{\text {a }}$ reimpressão do livro $\mathrm{A}$ imagem no ensino de Arte (2010), Ana Mae analisa as atualizações que pesquisadores e professores fizeram à sua proposta para constatar a mudança na figura de representação da abordagem e para ressaltar a importância da contextualização,

[...] a metáfora do triângulo já não corresponde mais à organização ou estrutura metodológica. Parece-nos mais adequado representá-la pela figura do ziguezague, pois os professores nos têm ensinado o valor da contextualização tanto para o fazer como para $\circ$ ver. $O$ processo pode tomar diferentes caminhos CONTEXTOIFAZER/CONTEXTOIVER Ou VER/ CONTEXTUALIZARIFAZER/CONTEXTUALIZARI Ou ainda FAZER ICONTEXTUALIZARIVER/CONTEXTUALIZAR (BARBOSA, 20I0, p. XXXIII).

No ziguezague a ação de contextualizar atravessa o fazer e o ver como constituidora de significados para o processo de aproximação às artes. Contextualizar envolve o universo estético vivencial que cerca as imagens ou outras manifestações da arte, envolver ver a cultura que cerca a arte, considerando a pluralidade dessa cultura que pode ser reconstruída de várias formas. Assim, de acordo com a autora, a contextualização não se trata apenas de saber sobre a vida do artista, mas sim, buscar também a reflexão sobre o contexto em que a obra foi produzida, quais sentidos podem estar envolvidos, aproximando o leitor do momento e do tempo em que o objeto de arte foi concebido, 
bem como o contexto da própria linguagem artística, visto que cada técnica utilizada traz consigo suas próprias especificidades e possibilidades de aprendizagem.

Por isso, no momento da contextualização de uma imagem ocorre, também, a leitura. Logo, a leitura passa a ser a visão de mundo do leitor que interage com a obra e seu contexto, produzindo um sentido particular a partir de suas próprias vivências e interpretações (PILLAR, 2014). O fazer, aquele que não deve ser confundido com a mera reprodução, é a criação que resulta da reflexão. Enquanto cria, a criança também está lendo sua produção, contextualizando com os saberes construídos.

A intencionalidade proposta na Abordagem Triangular diz respeito a recuperar as especificidades do campo arte na escola pelo exercício das ações/dimensões de ler/contextualizar/fazer. Cabe ao professor fazer escolhas referentes ao que apresentar e propor; para tanto precisa de conhecimentos estéticos que lhe possibilite reconhecer os códigos e valores culturais, seus e das crianças. Para tanto, é preciso exercer a escuta sensível às interações das crianças entre si e com o seu entorno. Estar atento aos repertórios das crianças e de suas famílias é fundamental para a organização de práticas pedagógicas com artes visuais. Sobre as finalidades de uma educação estética, Barbosa (1998, p. 4I) ressalta que,

[...] a educação estética não é ensinar no sentido da formulação sistemática de classificações de teorias que produzem definições de arte e análise acerca da beleza e da natureza. Este não é o principal propósito da educação estética. $\bigcirc$ que chamamos de educação estética de crianças, adolescentes e adultos é principalmente a formação do apreciador de arte.

A autora propõe uma educação estética integrada à leitura de imagens, em que o leitor é propositivo no olhar ao produzir sentido para o que vê. $\mathrm{Na}$ defesa da alfabetização para leitura de imagens, Barbosa (2010) salienta que preparar as crianças para o entendimento das artes visuais é prepará-las para o entendimento de qualquer imagem. Assim, a autora enfatiza a importância da presença de imagens nos processos de formação do leitor e acrescentar que é preciso um currículo que contemple, no processo dessa alfabetização, a relação ver/fazer. Acrescenta que um currículo organizado com esses princípios considera a criança em suas necessidades, seus interesses e características de desenvolvimento.

Assim posto, o ensino de artes visuais observa a percepção da nossa cultura e da cultura do outro, a leitura das imagens (da arte ou do cotidiano) e o fazer presente nas linguagens artísticas. Esse entrelaçamento de ações é permeado pela contextualização social, histórica e cultural, que envolve a peculiaridade de cada sujeito protagonista das experiências de ver/fazer em linguagens artísticas. 


\section{A linguagem do desenho na infância}

As práticas docentes na Educação Infantil são construídas na interação entre crianças e adultos mediada por linguagens. Para apreender o mundo cultural a criança imagina, fantasia e interage ludicamente com seu entorno, e expressa suas percepções de formas variadas. Ela não é um sujeito isolado, é ativo, histórico, faz parte de uma sociedade e precisa ter o adulto como um parceiro sensível que the possibilite espaço para vivenciar experiências educativas e estéticas. No intuito da fundamentação das práticas, tendo como foco a linguagem do desenho, buscamos pesquisas que enfatizam as interações que estão subjacentes no ato de desenhar.

Pillar (1996; 2012) para abordar, especificamente, a linguagem do desenho na infância toma como pressuposto a afirmação de que o conhecimento não se origina no sujeito, nem no objeto, mas se dá na interação entre ambos. Nessa interação, o sujeito, à medida em que constrói o objeto, se constitui como sujeito. $O$ desenho da criança é um objeto de conhecimento, para compreendê-lo a criança vai construir hipóteses na sua interação com esse objeto. O desenho da criança é resultado da interpretação que a criança faz dos objetos num contexto sociocultural e em uma época. A interação com ○ desenho the propicia construir hipóteses acerca da natureza e função desse sistema de representação. Para Pillar, a criança é o sujeito de seu processo de aproximação e construção de possibilidades de expressão na linguagem do desenho, aprende a desenhar através de sua atividade e significação desse objeto de conhecimento.

lavelberg (2006; 20I3), salienta que os grafismos das crianças apresentam imagens e muitos assuntos gerados por uma modalidade de interação criativa que se origina nos atos entre desenhistas, seus desenhos e a interação com o entorno. Dessa forma o desenho pode se constituir em um aspecto da vida da criança e pode seguir com ela enquanto sua intenção de desenhar for preservada. A autora ressalta que o desenho é uma produção autoral da criança, mas é, também, um objeto simbólico e cultural. $O$ desenho é linguagem expressiva e individualizada, influenciada pela cultura. A criança desenha regida pelo que concebe sobre o desenho, para que as possibilidades de desenhar sejam ampliadas é fundamental que ocorra a interação com um meio onde o desenho é validado como ação infantil.

Derdik (2007; 2010; 20I8), defende a concepção de desenho como campo expandido, ato orgânico de delinear percursos no espaço em que o corpo se transforma na ponta do lápis para deixar rastros de um traço pessoal e criativo. Para autora o desenho é a linguagem basilar de outras formas de representação. É a ossatura das linguagens visuais e a linguagem mais antiga que atravessa todo arco civilizatório. No trabalho da autora, como artista, a matéria extrapola a dimensão plana do pictórico para se transformar em esculturas e instalações feitas com linhas que ocupam determinada 
espacialidade. Dá-se assim a passagem do bi para o tridimensional na qual a linha é matéria polimorfa que se projeta do plano para o espaço.

Figura I - Montagem da instalação Arcada (2013)

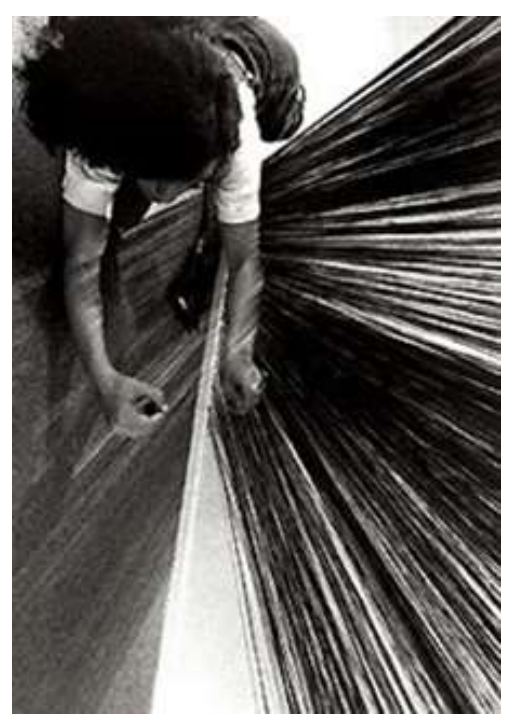

Fonte: http://solangeviana.blogspot.com/2013/0I/edith-derdyk-utiliza-500-metros-de.html

Derdik defende o desenho como experiência vivenciada na conjunção entre corpo, tempo e espaço, afirma que o percurso da linha que desenha, modula, modela, territorializa o espaço e convoca temporalidades (DERDIK, 20I8). Para autora, todo conhecimento vem da experiência do sujeito com a matéria daquele conhecimento, experiência que se produz na percepção de mundo por um corpo sensível. Em referência à vivência dessa linguagem por crianças, Derdik salienta que ao desenhar a criança canta, dança, teatraliza, imagina ou até silencia. Assim, a experiência de desenhar convoca outras linguagens possibilitando uma grande caminhada no imaginário. $O$ gesto das crianças pequenas, ao experienciar o traçado de linhas, não tem como finalidade a representação ou cópia de formas. A linha é mais que o contorno da forma, e o gesto de desenhar abre caminhos para além do lápis e papel.

\section{Percursos metodológicos}

O aporte metodológico que norteou este trabalho observou princípios sobre Arte/Educação e sobre o trabalho com a linguagem do desenho na infância para construção de uma sequência didática, em diálogo com as crianças. Sobre a concepção de sequência didática, Zabala afirma que se trata de "um conjunto de atividades ordenadas, estruturadas e articuladas para a realização de certos objetivos educacionais, que têm um princípio e um fim conhecidos tanto pelos professores como pelos alunos (...)” (ZABALA,1998, p.l8). Para planejar as ações do projeto Desenho em gestos brincantes, observamos a relação entre as concepções de sequência didática em Zabala e experiência educativa 
O meu traço brinca com o seu: experiências estéticas, interações e desenhos na Educação Infantil

em Dewey. Para Dewey a experiência é educativa quando gera novas experiências, isto é, tem continuidade em outras experiências. A organização da sequência didática, e das experiências, ocorreu pautada pela observação das formas de interação com sujeitos e objetos. A experiência pode, em seu planejamento, se pretender educativa, mas, ela se tornará educativa na recepção/atuação daqueles envolvidos na experiência. Esse fato justifica a relevância de observar o protagonismo das crianças durante as experiências.

Além disso, ainda no que se refere à metodologia, destacamos a pesquisa-intervenção, que entendemos como o processo que se dá a partir das interações entre o pesquisador e o outro, em um compartilhamento de experiências e na construção coletiva dos conhecimentos. É um encontro entre os sujeitos que intencionalmente associa o pensamento à prática, de forma que busque uma transformação na realidade e nos sujeitos.

Intervir significa criar condições para que pesquisador e sujeitos da pesquisa se distanciem de suas experiências e reflitam sobre elas a partir do olhar alheio e, assim, possam libertar-se de verdades que se apresentam como absolutas ao vislumbrarem outras perspectivas e sentidos possíveis para a compreensão de suas experiências e dos discursos que se atravessam (JOBIM; SOUZA, 20II, p. 42).

A organização da sequência didática foi pautada, também, pela consideração do entrelaçamento entre as ações de ler/contextualizar/fazer, que, para além de ações, se configuram como dimensões do sentir/pensar e se expressar em linguagens artísticas.

Com o objetivo de desencadear o projeto, começamos a observar os desenhos das crianças. Propusemos, inicialmente, que as crianças desenhassem seu final de semana, uma prática recorrente no cotidiano daquela sala de referência. $O$ desenho de final de semana era realizado, geralmente, no início da segunda feira, após uma roda de conversa em que as crianças relatam algumas vivências ocorridas durante final de semana. Nessa situação, as crianças encadeavam narrativas sobre momentos passados com as famílias, relatos de passeios, brincadeiras, vivências felizes ou tristes, eufóricas ou frustrantes. A proposta para que as crianças desenhassem algo que lhes havia marcado no final de semana, para nós, destinava-se à observação de como as crianças agiam enquanto desenhavam e, ao mesmo tempo, permitiria a leitura do traçado de linhas no papel, específico de cada criança.

Algumas crianças se demoravam no desenho, outras preenchiam o papel rapidamente, umas crianças se preocupavam em representar algo da sua narrativa oral, durante a roda de conversa, outras escolhiam temáticas alheatórias para o seu desenho. Havia, também, aquelas que experimentavam linhas no papel, sem que houvesse preocupação com a representação de algo. $O$ grupo nos apresentou uma diversidade de traçados, intencionalidades e formas de se relacionar com o desenho.

Olhar de professor, Ponta Grossa, v. 24, p. I-25, e- I756I.074, 202 I.

Disponível em <https://revistas2.uepg.br/index.php/olhardeprofessor> 
Figura 2 - Circo

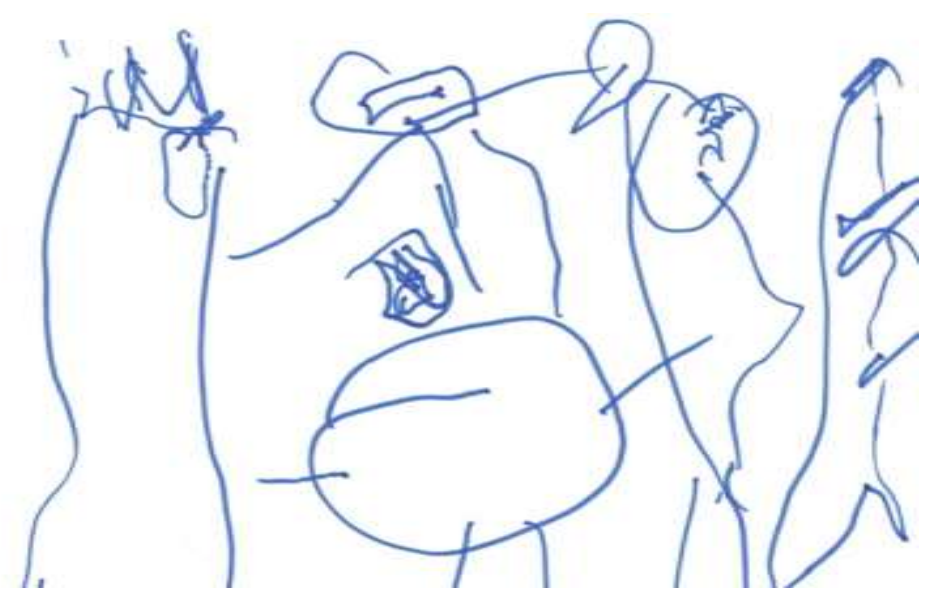

Fonte: acervo pessoal, 2019.

No desenho acima a criança apresenta uma cena da ida ao circo com a família, realizando o traçado de contorno de linhas, com o uso de uma só cor. Prioriza a representação da figura humana como elemento de composição do desenho. Ela se desenha no centro da imagem, estando acompanhada por seus pais (figuras mais altas). Do lado direito há a representação da porta do circo.

Figura 3 - Eu na piscina

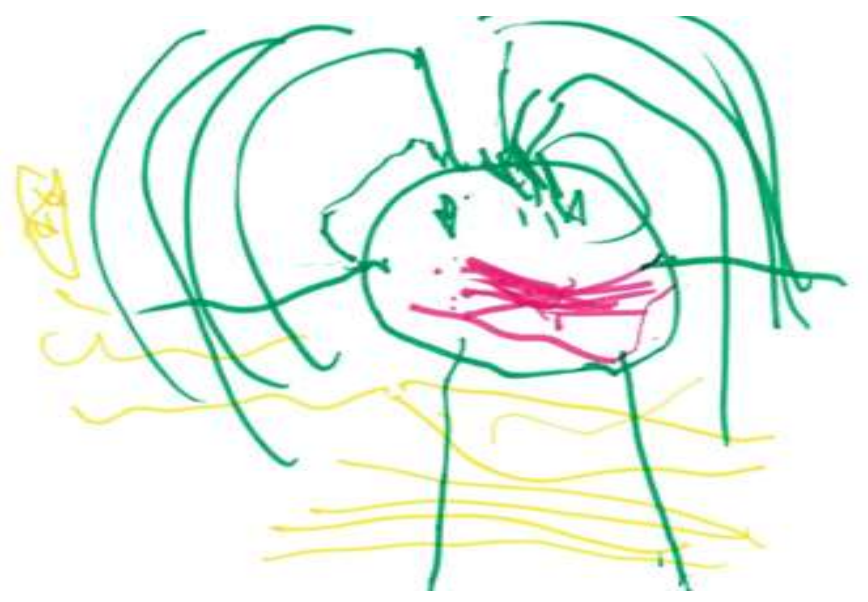

Fonte: acervo pessoal, 2019.

$\mathrm{Na}$ imagem acima a criança se coloca no centro da composição, grafada com canetinha verde e rosa, estando em relação com a linhas claras que representam a água da piscina.

Durante a observação da vivência do desenho do final de semana, percebemos vários elementos que ajudariam a dar continuidade ao projeto. As temáticas, as cores e as formas com as quais as crianças optaram por produzir marcas no papel se tornaram referências para desencadear outras propostas. 
O meu traço brinca com o seu: experiências estéticas, interações e desenhos na Educação Infantil

Convivendo com o grupo, para elencar situações em que as crianças desenhavam, constatamos que elas estavam acostumadas a desenhar com os mesmos suportes e riscadores. Desenhavam, geralmente, em pé no quadro branco; sentadas à mesa produzindo marcas no papel $A 4$ ou $A 3$, e, às vezes com giz no chão. Diante disso, optamos por proporcionar diferentes tipos de suportes, para que a turma pudesse experimentar a linguagem do desenho de maneiras mais diversificadas. Trouxemos superfícies de papel em formato $A 3$ e A6, além de papeis em formato de círculo, retângulo e quadrado, em variados tamanhos

Figura 4: suportes em formatos diferentes.

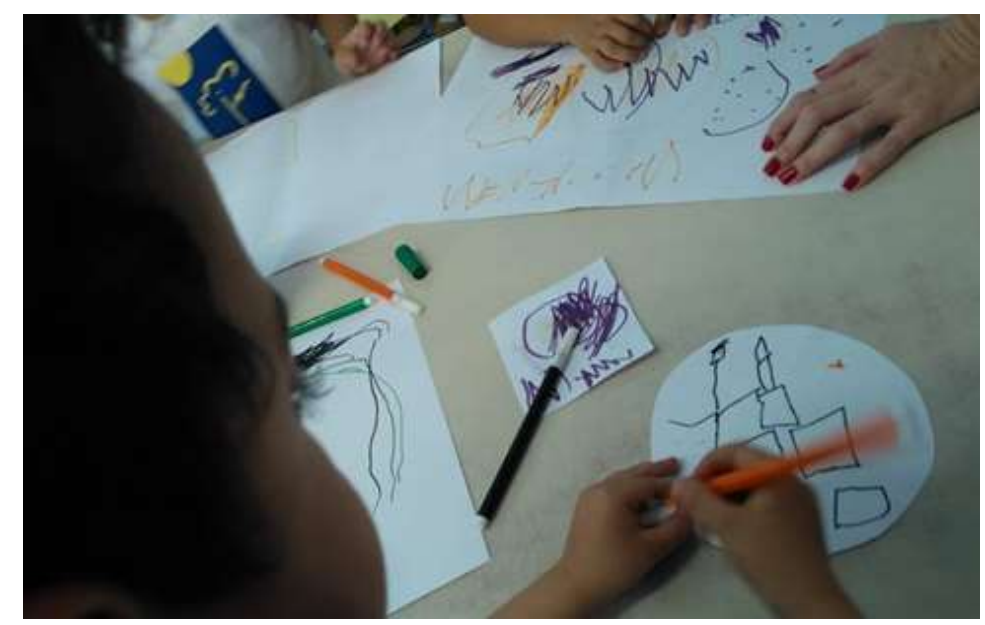

Fonte: acervo pessoal, 2019.

Em um outro momento, levamos os desenhos produzidos para a turma, com o objetivo de que as crianças pudessem fazer a leitura dos seus próprios desenhos, bem como dos desenhos de seus colegas. A leitura de imagens, no trabalho com artes visuais na infância, não se limita ao contato com imagens produzidas por adultos, estende-se à apreciação das imagens produzidas, também, pelas próprias crianças. A situação de leitura, aqui relatada, ocorreu de forma coletiva. Trouxemos as imagens e solicitamos que cada criança identificasse a sua. Após a identificação, as crianças, que desejassem, poderiam apresentar o seu desenho para os colegas, ou permitir que nós mostrássemos seu desenho (apenas segurar o desenho para que a criança fizesse inferências). Algumas crianças não se dispuseram a expor suas imagens, correndo para guardar seus desenhos nas mochilas, mas, a maioria aceitou o desafio. 
Figura 5: leitura dos desenhos

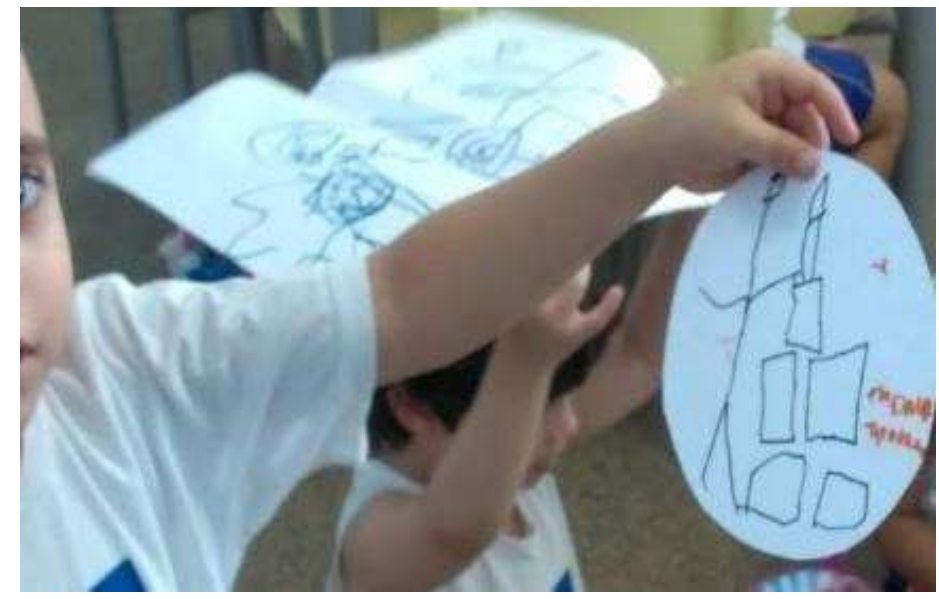

Fonte: acervo pessoal, 2019

O contato com as crianças nas experiências de desenhos nos desafiava a demorar o nosso olhar para as especificidades do processo de produção gráfica de algumas crianças. Percebemos que uma das crianças, B., gostava de criar seus desenhos em grandes linhas contínuas. Com movimentos calmos e reflexivos, ela desenhava continuamente até constatar que não havia mais espaço em sua folha. Por isso, optamos por trazer referências de artistas que produziam desenhos em linha contínua, para que fosse possível dar visibilidade ao estilo de B. Escolhemos imagens da internet e imagens da literatura, além de propor atividades que ampliassem o repertório das crianças sobre o desenho em linha contínua. $\mathrm{Na}$ sala de multimídia, apresentamos para as crianças o vídeo do estúdio francês Differantly. $\mathrm{Na}$ apreciação do audiovisual as crianças foram colocadas diante da produção de desenhos de linha contínua que se transformava em animais com os movimentos da linha, realizados por um artista que desenhava sem tirar o lápis do papel.

Figura 6 - As linhas contínuas de B

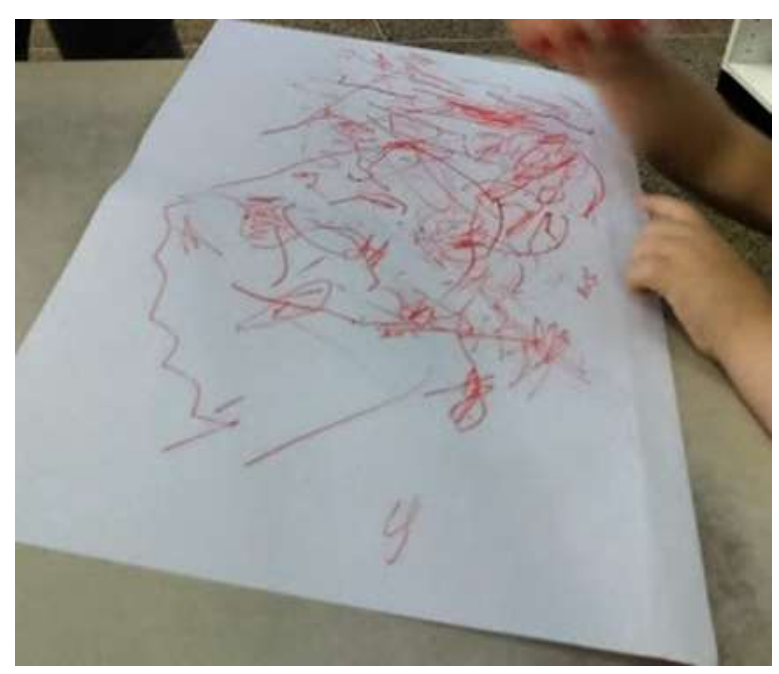

Fonte: acervo pessoal, 2019.

Olhar de professor, Ponta Grossa, v. 24, p. I-25, e-1765I.074, 202 I.

Disponível em <https://revistas2.uepg.br/index.php/olhardeprofessor> 
O meu traço brinca com o seu: experiências estéticas, interações e desenhos na Educação Infantil

Figura 7 - Imagem do estúdio Differantly

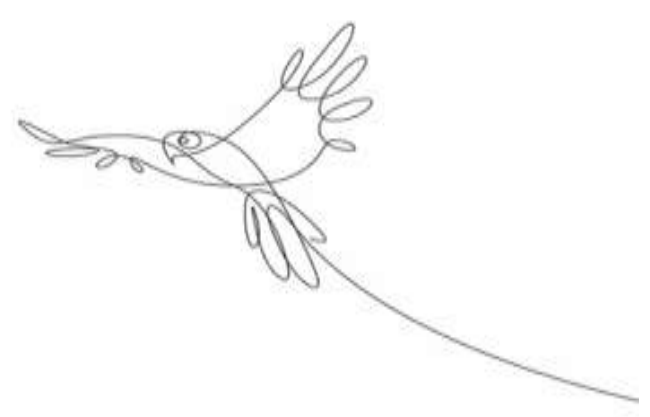

Fonte: https://www.designerd.com.br/ilustrando-animais-com-apenas-uma-linha/

A pesquisa sobre quais imagens poderiam ser apresentadas às crianças para ampliação do seu repertório gráfico, conduziu o nosso olhar para as ilustrações da literatura. Para dar continuidade as propostas de leitura e produção na linguagem do desenho, escolhemos o livro $\bigcirc$ arame de Alexandre, escrito e ilustrado por Sieb Posthuma. A escolha desse objeto ocorreu após a análise do plano de conteúdo e plano de expressão que constituíam a obra. A relação entre expressão e conteúdo presentificava efeitos de sentido adequados aos objetivos do projeto de desenho. Para Semiótica Discursiva os textos são compostos por dois planos, o plano de conteúdo - o que o texto diz; e o plano da expressão - como o texto faz para dizer do seu conteúdo (BARROS, 2005). No Arame de Alexandre, o ilustrador se utiliza de uma linha contínua para contar a história de Alexander Calder (1898-1976). Calder trabalhou com esculturas modernas usando fios de arame, chapas metálicas e cores saturadas. Sieb Posthuma se baseia no percurso da produção artística de Calder para desenhar a ilustração do livro e contar a história de um personagem chamado Alexandre, que criava tudo que precisava com arame.

Figura 8 - $\bigcirc$ arame de Alexandre (capa)

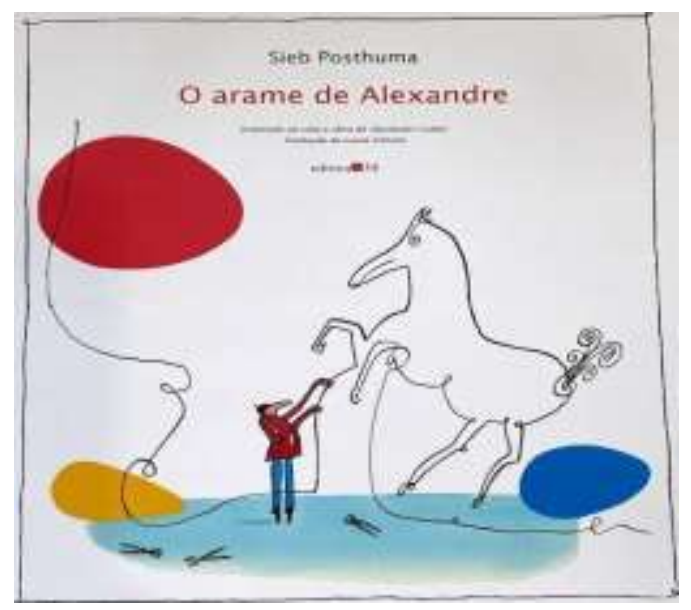

Fonte: http://www.editora34.com.br/detalhe.asp?id=866

Olhar de professor, Ponta Grossa, v. 24, p. I-25, e-1756I.074, 202 I.

Disponível em <https://revistas2.uepg.br/index.php/olhardeprofessor> 
Em linha contínua, que na narrativa é a representação do arame de Calder, surgem nas páginas do livro pessoas, bichos, móveis, ruas, prédios e muitas outras figuras. Os desenhos remetem a momentos distintos da obra de Calder, indo das esculturas em arame até a construção de objetos móveis - compostos por linha e cor - os móbiles.

As estratégias de mediação para promover a interação das crianças com o livro foram diversas. A primeira aproximação das crianças ao objeto ocorreu de forma espontânea, o livro foi colocado junto aos demais livros, na sala de referência havia um cantinho com livros que as crianças podiam acessar livremente. Além desse espaço com livros, diariamente, as crianças participavam de práticas de leitura, denominada de contação de histórias pelas professoras. Tal situação de leitura, iniciava com os livros dispostos em um grande tapete, as crianças sentadas no tapete escolhiam um dos livros para folhear. Após esse momento, a professora, ou uma das crianças, elegia uma das obras para a leitura/contação de história. A escolha do Arame de Alexandre desencadeou o momento de leitura mediada, que foi iniciado com a apresentação da imagem da capa do livro, e continuou com a contadora seguindo a linha, deixada pelo autor/ilustrador para tecer a narrativa de Alexandre.

Figura 9 - Alexandre tinha um arame

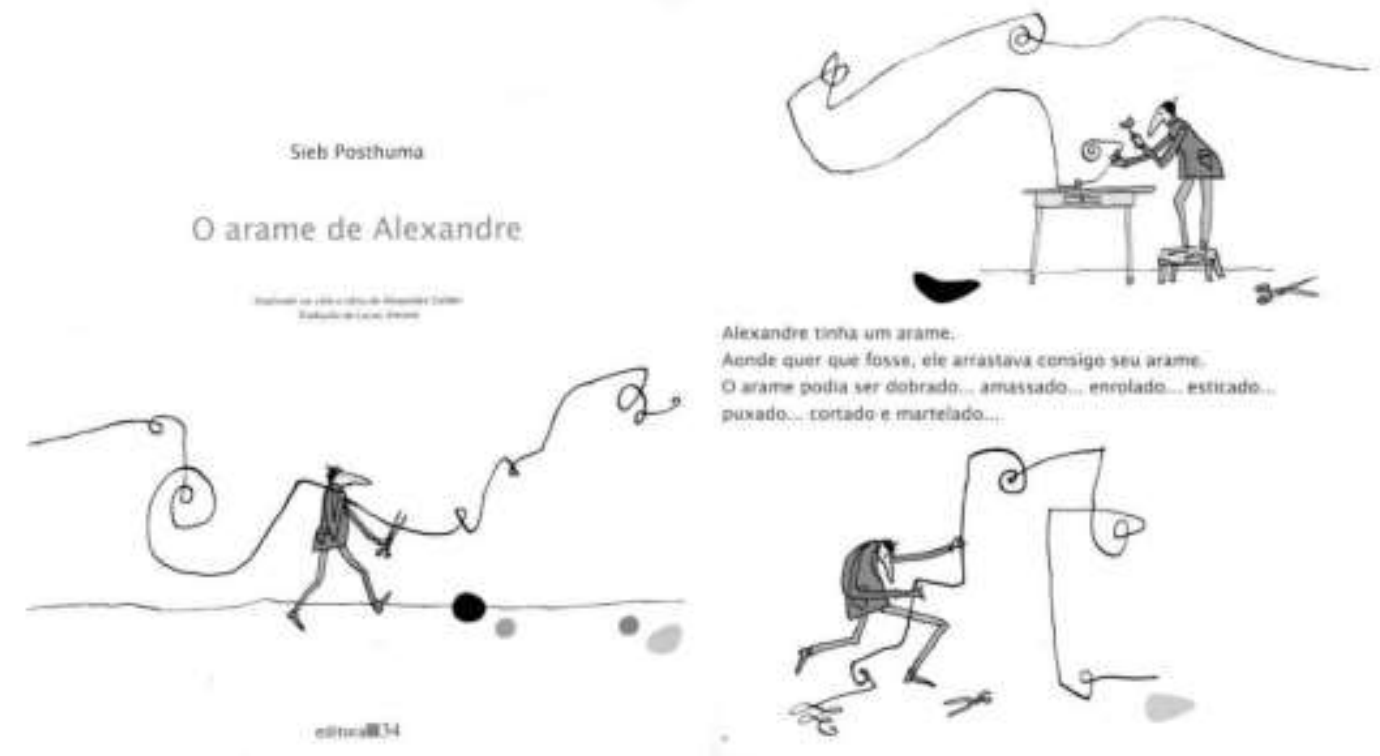

Fonte: POSTHUMA, S. O arame de Alexandre. São Paulo: Editora 34, 20I5. p. 5 e 6

Após a primeira leitura, voltando novamente para o início do texto, incentivamos as crianças a expressarem comentários sobre a trama de imagens que conta a história. 
- Como o desenhista dessa história fez? Será que parece com aquele artista que não tirava o lápis do papel?

"Parece sim!"

- E por que ele tem um arame?

"Ele trabalha com um arame"

“Como ele desenhou o rolo?" [referência ao desenho de uma espiral]

"Ele enrolou o arame"

"Ele fazia [os bichos] de arame"

"Ele faz tudo de arame"

"Ele comprou uma mola e fez de arame [o dinossauro]"

"A nuvem não era de arame"

"Agora tem irmãos gêmeos"

"Parece um pouco com um macaco"

"Ele não fez nada e depois fez tudo. Ele só continuou fazendo." [referência a imagem de um desenho abstrato, que na história remete à mudança de estilo de Calder]

As crianças estabeleceram relações entre as ilustrações do livro e os desenhos em linha contínua aos quais já haviam sido apresentadas. Foram minuciosas nos comentários sobre o trabalho do ilustrador, observaram, estabeleceram relações intertextuais com o audiovisual, sobre o estúdio Differantly, e formularam questões sobre o processo de produção dos desenhos.

Para conhecer melhor ○ Alexander, no qual se baseava o livro, as crianças foram apreciar vídeos sobre o circo de arame de Alexander Calder. $O$ artista americano Alexander Calder, que se destaca como importante referência em arte cinética no século XX, no ano de 1926, em Paris, deu forma ao seu interesse pelo mundo circense ao criar o Cirque Calder. No início do audiovisual, Calder aparece com duas malas, de onde retira objetos para montar o picadeiro do circo. Em seguida, ele vai colocando os personagens circenses neste picadeiro, com a preocupação de apresentar ao espectador o processo de manipulação que dá movimento aos mesmos - trata-se de esculturas manipuláveis que podiam ser transportadas para onde Calder desejasse. Em alguns dos personagens a linha de contorno era bem perceptível. Os desenhos de Calder, transformados em esculturas, causaram encantamento no grupo. O circo, construído com miniaturas de artistas, objetos circenses e animais, produzidos com arames, madeira, couro, tecidos e outros materiais, as imagens, capturou os olhares das crianças e desencadeou comentários. 
Figura 10 - Circo Mínimo de Alexander Calder.

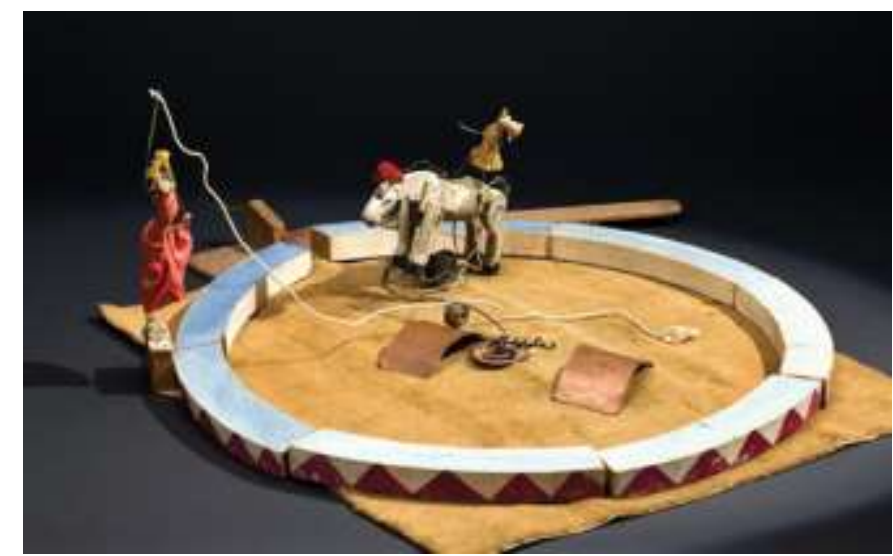

Fonte: (1263) Alexander Calder performs his "Circus" | Whitney Museum of American Art YouTube).

Após a experiência de leitura do livro, e do audiovisual, sobre os desenhos/esculturas de Alexander Calder, trouxemos uma outra proposta de produção de imagens: tal qual Alexandre, faríamos novamente os desenhos em linha contínua, no entanto, no lugar do arame, dessa vez faríamos no papel. A experiência proporcionou momentos de experimentação e aprendizagem. As crianças começaram a experimentar tracejar a linha contínua no papel, mas, após um tempo, retiravam o lápis da folha e decidiam prosseguir o desenho de outras maneiras, esquecendo da proposta inicial. Optamos, então, por fazer desenhos no quadro, de forma que a turma pudesse fazer leituras, acompanhar e dar sugestões sobre a produção de cada criança. Dessa vez, as crianças ficaram ainda mais empolgadas e conseguiram desenvolver desenhos em linha contínua, mantendo a intencionalidade.

Figura I I - Desenho de linha contínua no quadro.

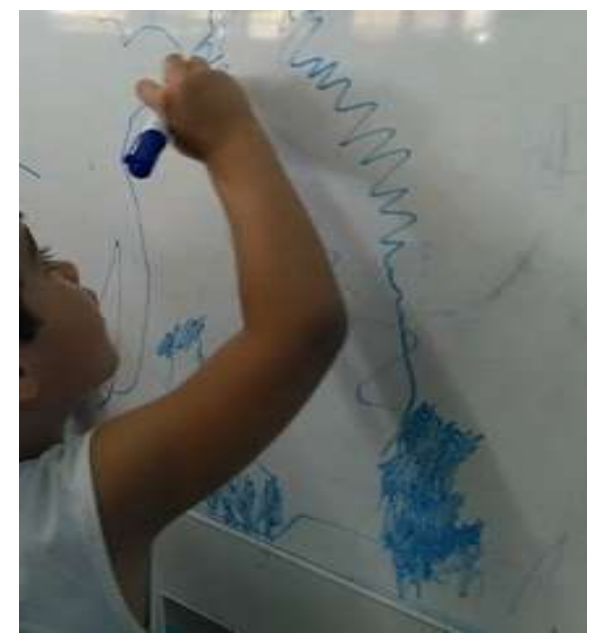

Fonte: acervo pessoal, 2019

Olhar de professor, Ponta Grossa, v. 24, p. I-25, e-1765I.074, 2021.

Disponível em <https://revistas2.uepg.br/index.php/olhardeprofessor> 
A investigação sobre o percurso que a linha poderia tomar, ao ser assumida como extensão do corpo das crianças, nos fez diversificar ainda mais as vivências com a linguagem do desenho. Trouxemos barbantes e solicitamos às crianças que brincassem de fazer desenhos com aquela linha. Tais desenhos poderiam ser modificados, se assim desejassem. Diante dos colegas, cada criança experimentou jogar o barbante no ar, observar seu percurso, para, ao final, colocá-lo em cima de uma cartolina azul e dar forma àquela linha. No processo, a linha ganhava o espaço movida pelo gesto da criança, o barbante, jogado no meio da roda, diante dos olhares do grupo, voava para cair no chão ou na cartolina. Algumas crianças planejavam a distância e a força para o lançamento do objeto, mirando o suporte que estava no chão. A criança que lançava o barbante poderia ajustar suas formas e podia convidar um dos colegas para modificar o seu desenho. Depois desse momento de desenho coletivo compartilhado, que colocou o grupo para vivenciar a natureza efêmera do traço, cada criança foi desafiada a criar formas com o barbante usando cola para que o desenho se tornasse fixo.

Figura 12 - Desenho com barbante

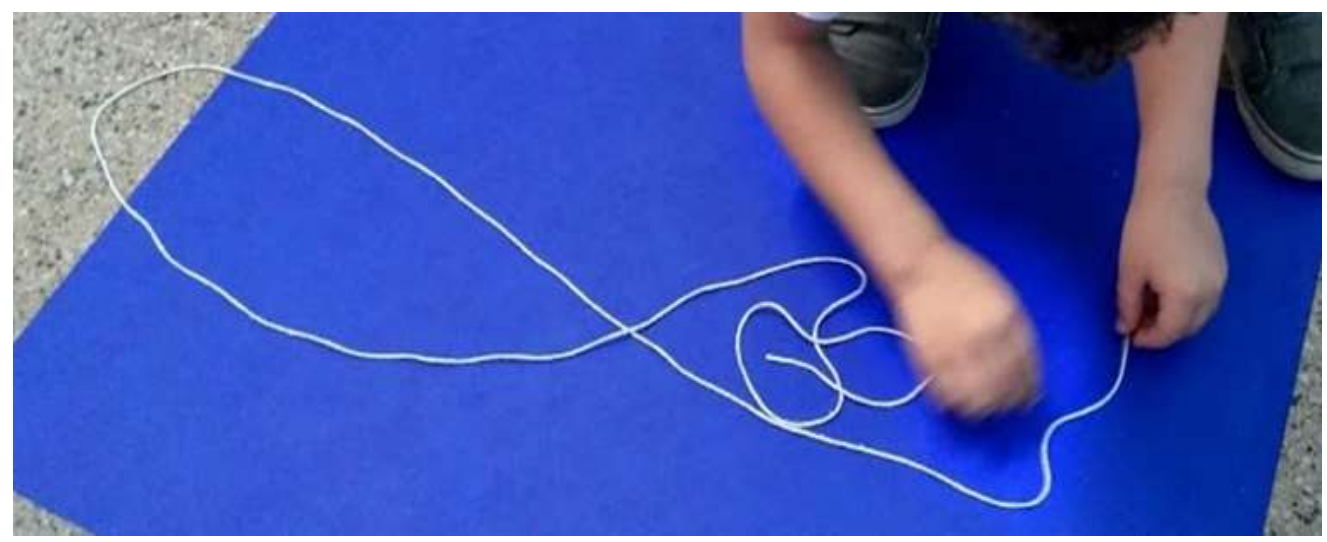

Fonte: acervo pessoal, 2019

Concebendo que o percurso da linha pode ser mobilizado por diferentes partes do corpo, buscamos motivar as crianças a explorarem as possiblidades de interação do corpo com a espacialidade e os suportes durante $o$ ato de desenhar. Trouxemos vídeos que apresentavam o percurso criativo de artistas que utilizam outras partes do corpo para desenhar, como Huang Guofu, que desenha com a boca e com o pé direito; e o vídeo com Heather Hansen produzindo sua tela Empty Gestures (Gestos Vazios), que mostra um exemplo de pintura cinética, na qual os movimentos do corpo produzem gestos e marcas na superfície. 
Figura 13 - Huang Goufu

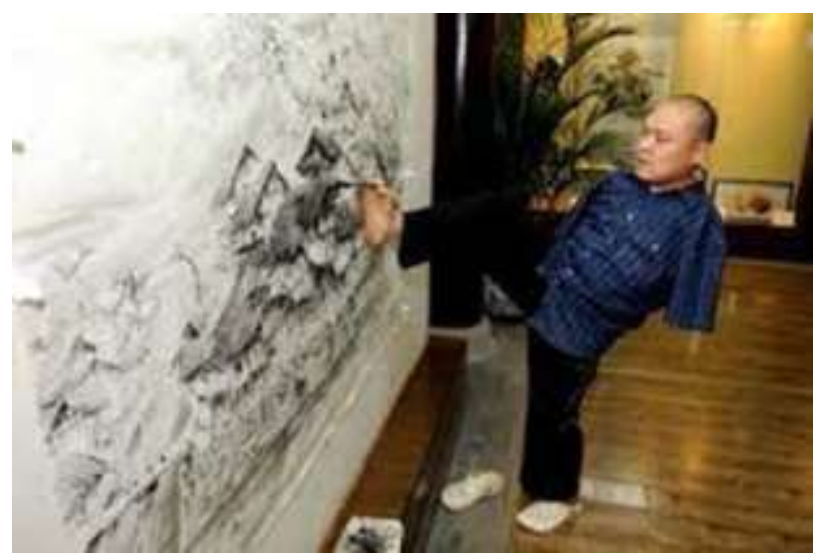

Fonte: https://www.deficienteciente.com.br/huang-guofu-superando-a-arte-sem-os-bracos.html

Figura I4 - Gestos vazios

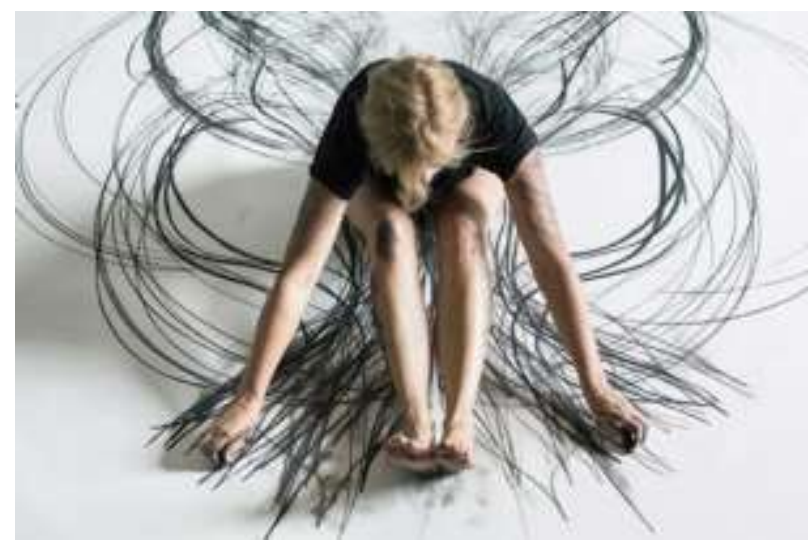

Fonte: https://fujocka.wordpress.com/2013/I0/0I/gestos-vazios-de-heather-hansen/

As crianças se mostraram muito interessadas em experimentar as técnicas apresentadas, o que gerou muitos desenhos feitos com os pés, boca, axilas e diversos movimentos corporais registrados no papel.

Figura I 5 - Desenho com a boca

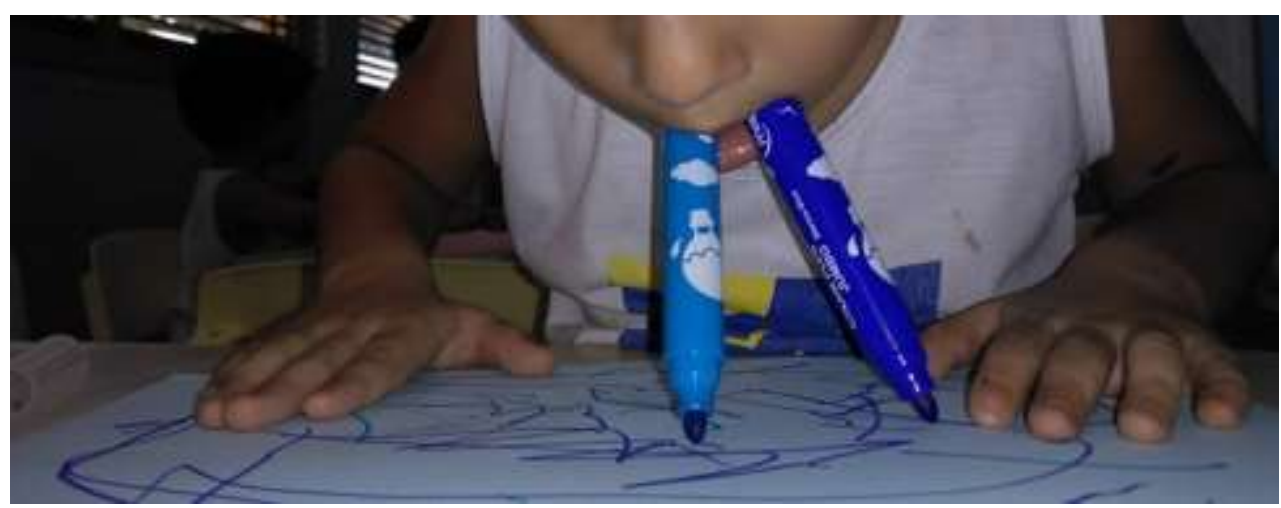

Fonte: acervo pessoal, 2019

Olhar de professor, Ponta Grossa, v. 24, p. I-25, e-1765I.074, 202 I.

Disponível em <https://revistas2.uepg.br/index.php/olhardeprofessor> 
Figura 16 - Desenho com os pés

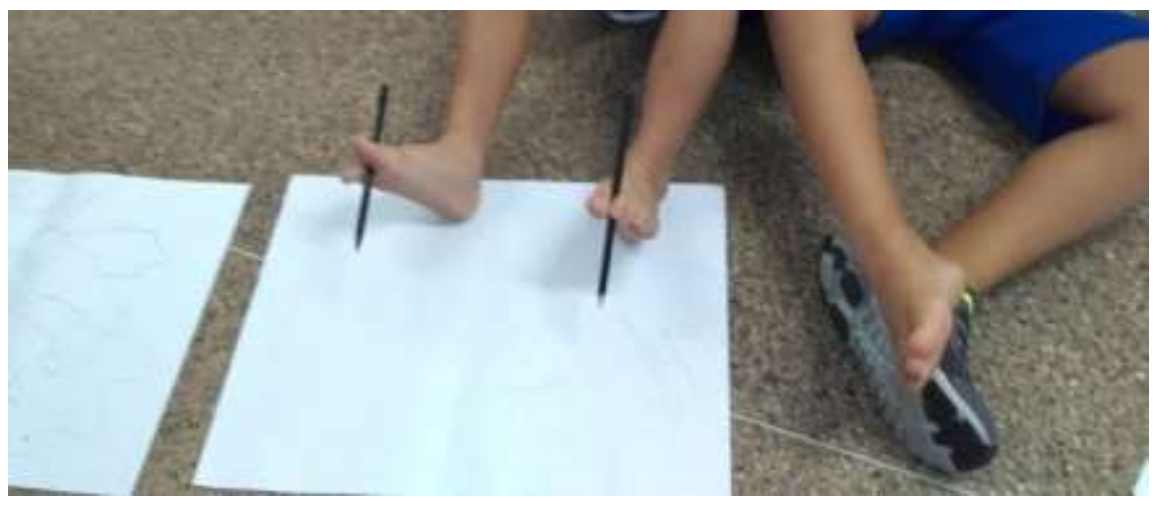

Fonte: acervo pessoal, 2019

Como desdobramento do projeto Desenho em gestos brincantes, continuando a sequência de experiências, questionamos às crianças como os artistas faziam para pintar nos tetos das igrejas, mostrando o exemplo da Capela Sistina, pintada com a técnica afresco por Michelangelo Buonarroti (1475 - 1564). Para vivenciar um pouco do desafio desse artista, além de investigar outros modos de estar corporalmente durante a produção de desenhos, cobrimos as mesas (em cima e embaixo), o chão, as paredes e portas com um extenso papel kraft instigando as crianças à produção de desenhos, se ajustando corporalmente à espacialidade que o suporte colocado de formas diversas lhes trazia como desafio.

Figura 17 - Desenho embaixo da mesa

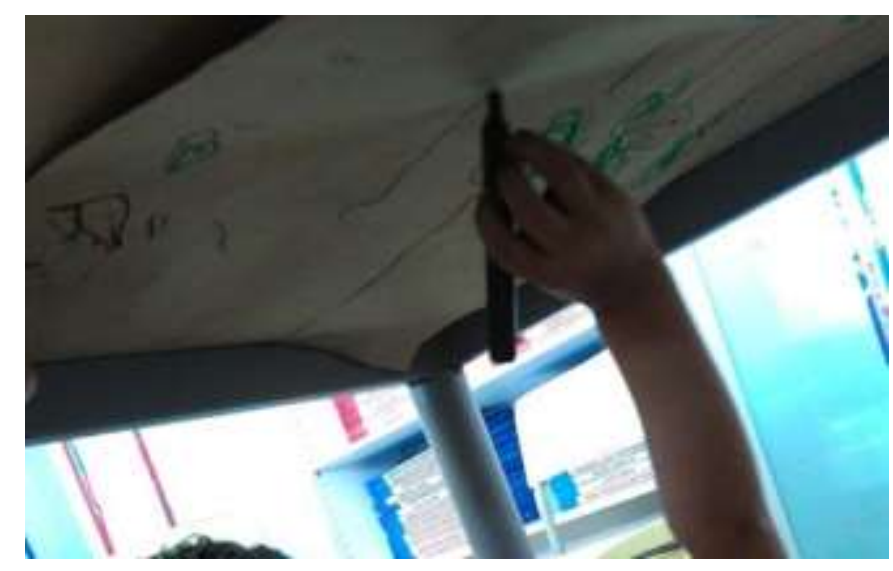

Fonte: acervo pessoal, 2019 
Figura 18 - Desenho na porta

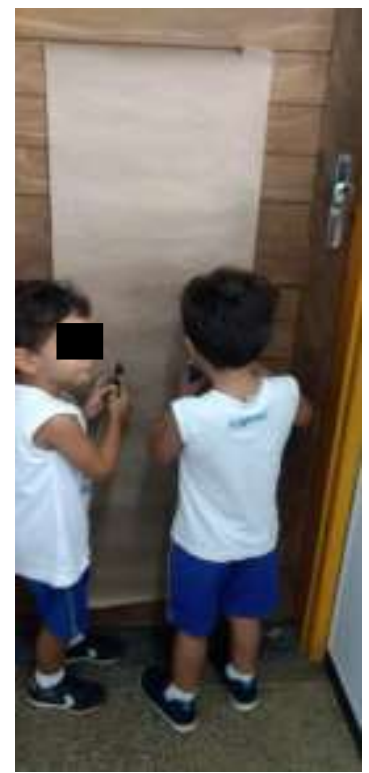

Fonte: acervo pessoal, 2019

Figura 19 - Desenho na parede em plano baixo

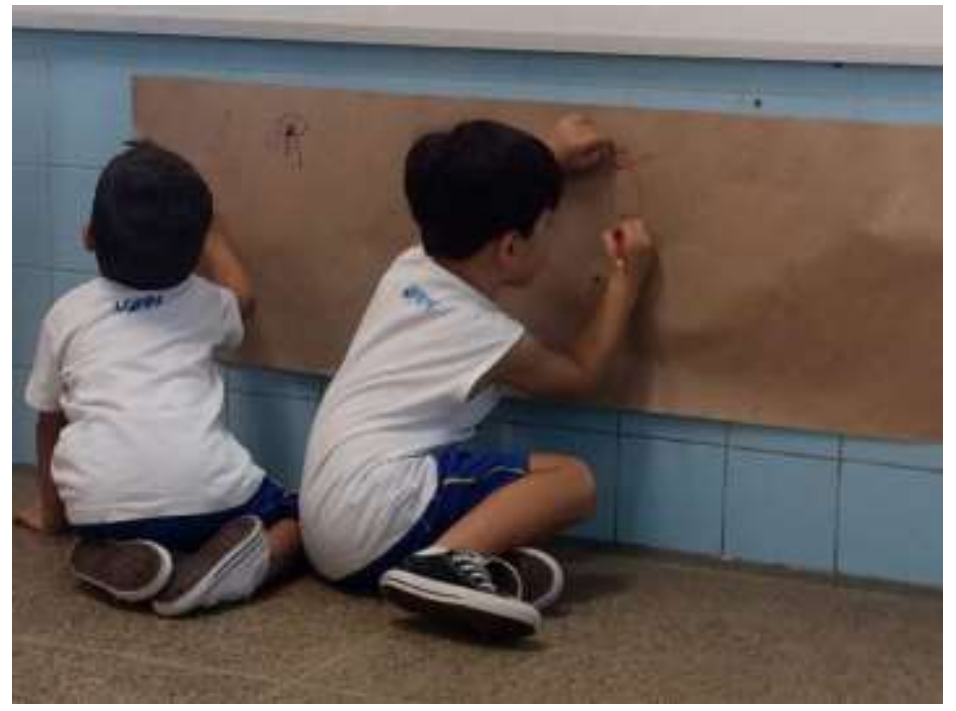

Fonte: acervo pessoal, 2019

Com o objetivo de possibilitar outras leituras e vivências de desenho, propusemos outra situação de apreciação de imagens da arte, na literatura, lemos o livro Jeremias desenha um monstro, de Peter Mccarty, no qual um garoto, sem amigos, desenha um monstro para lhe fazer companhia. A narrativa se desencadeia com o mostro solicitando que Jeremias dê forma aos seus desejos: comidas, roupas, objetos, entre outros. Muito exigente, o monstro causa incômodos ao garoto. Como desfecho da história, Jeremias desenha um bilhete de ônibus para o mostro, somente de ida. $O$ monstro entra 
no ônibus, a contragosto, e segue o seu caminho. $O$ menino se volta para outras crianças, terminando a história com amigos para brincar na rua. A partir da leitura da ilustração do livro Jeremias desenha um monstro, trabalhamos com a ideia de representação, ao pedir que a turma criasse seus próprios monstros e os registrassem por meio de desenhos.

Figura 20 - Jeremias desenha um monstro (ilustração da capa)

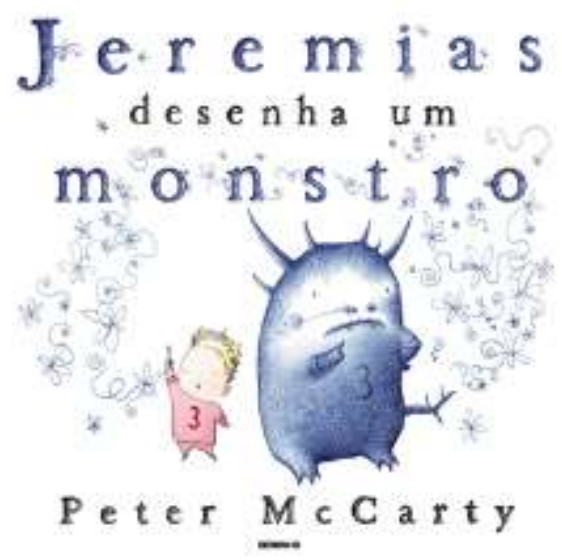

Fonte: https://www.amazon.com.br/Jeremias-Desenha-Monstro-Peter-McCarty/dp/8525051950

Nos papéis, e no corpo das crianças, surgiram monstros de variadas formas e tamanhos, todos diferentes da imagem de referência apresentada quando da leitura da ilustração do livro. Nessa situação elas acionaram as práticas de desenho vivenciadas anteriormente, algumas crianças experimentaram desenhar o monstro com as canetinhas presas na boca, outras lembraram do desenho em linha contínua para alongar a representação do corpo de seu monstro.

Figura 2l - Desenho do monstro

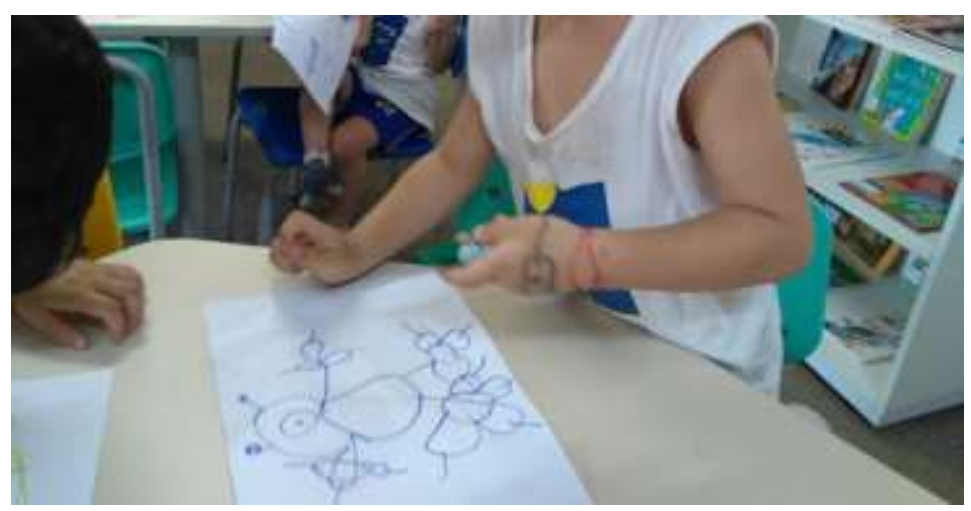

Fonte: acervo pessoal, 2019

Para finalizar o projeto, levamos para a sala de referência todo o material produzido pelas crianças. Os desenhos foram dispostos, no tapete no meio da roda, para que cada criança escolhesse 
alguns para uma apreciação individual. Elas passearam em volta dos desenhos, olhando de cima para baixo, buscavam os seus desenhos. Mas, algumas crianças, também, apreciavam o seu desenho estabelecendo relações com os desenhos dos colegas. Durante esse momento, começamos a questionar o que poderia ser feito com todos os seus desenhos. Assim, com as crianças, pensamos em possibilidades para mostrar os trabalhos para as outras crianças da escola, familiares e comunidade.

Falas das crianças sobre a leitura dos desenhos produzidos e organização da exposição:

O que vamos fazer com todos esses desenhos que fizemos? [professoras]

"... pode mostrar os desenhos pros nossos amigos"

“... levar os desenhos pra casa e mostrar pros pais"

“... pode doar e fazer outros desenhos"

"Ou a gente pode colar nas mesas"

“...também pode colar nas paredes"

"E no teto!"

“... pode cantar uma música quando for mostrar os desenhos” (Explicação que faz referência ao ambiente de uma exposição).

"A gente tem que mandar uma carta para os pais avisando"

"Vai dar um trabalhão pra colar tudo"

Todos precisam ajudar [professora]

"Pode ser lá fora também"

"Meu pai pode pendurar as coisas lá em cima, ele é bem alto"

"Pode colar nas portas e nos armários"

Estando diante do material gráfico, e da reflexão das crianças sobre como mostrar a produção a outros, construímos juntos a exposição Gestos e marcas brincantes: exposição de desenhos da Turma 2. As crianças participaram de todo o processo, desde a escolha do nome, local e montagem, bem como nos momentos de mediação para os visitantes. Os desenhos foram dispostos nas paredes do corredor das salas de Educação Infantil, para que as crianças e professores de outros grupos pudessem ver. Escolhemos um dia para convidar os familiares das crianças para apreciação dos desenhos. Neste dia, as crianças atuaram como mediadores que aproximavam os adultos das imagens. Durante a exposição mantivemos um espaço, com riscadores e papéis de tamanhos e formas diferente, para que adultos e crianças desenhassem. Esta proposição de interação fazia com que as crianças, sem precisar de muita explicação, fizessem o convite ao público para também exercer o desenho em gestos brincantes. A atuação das crianças durante todas as situações de aprendizagem do projeto - vivenciando experiências, exercitando seu protagonismo e coparticipando da organização do ato pedagógico - deu 
O meu traço brinca com o seu: experiências estéticas, interações e desenhos na Educação Infantil

a elas a segurança para saber dizer para outros, a seu modo, o que havia ocorrido até chegar às imagens expostas.

Considerações para continuar desenhando

O título do artigo "O meu traço brinca com o seu" é significativo da dimensão interativa de um projeto que convidou/desafiou as crianças para experiências com o ato de desenhar. $O$ traço que brinca não se produz sozinho, convida outros, aproxima-se de imagens e de sujeitos produtores de imagens, sejam eles artistas ou outras crianças. Compreendendo que a interação ocorre atravessada por referências culturais, é possível afirmar que o traço é, ao mesmo tempo, pessoal e cultivado. Acrescente-se a essa constatação a consideração de que o corpo brincante gesta e gera a linha que se expande no espaço como traço que delineia um percurso, no nosso caso um percurso para encontrar outros traços.

\section{Referências}

BARBOSA, A. M. A imagem no ensino de Arte: anos 1980 e novos tempos. $7^{\text {a }}$ ed. rev. São Paulo: Perspectiva, 2010.

BARBOSA, A. M. Tópicos Utópicos. Belo Horizonte: C/Arte, 1998.

BARROS, D. L. P. Teoria semiótica do texto. São Paulo: Ática, 2005.

BRASIL, Ministério da Educação. CNE/CEB. Diretrizes Curriculares Nacionais para a Educação Infantil. Brasília, 2010.

BRASIL, MEC, Base Nacional Comum Curricular - BNCC, versão aprovada pelo CNE, novembro de 2017. Disponível em: http://basenacionalcomum.mec.gov.br/ Acesso em: 04 junho 2020.

DERDIK, E. Formas de pensar o desenho. Porto Alegre: Zouk, 2010.

DERDIK, E. (Org.). Monografia livro Edith Derdik de 1997 a 2017. São Paulo: A edições, 2018.

DERDIK, E. (Org.). Disegno. Desenho. Desígnio. São Paulo: Senac, 2007.

DEWEY, J. Arte como experiência. Tradução de Vera Ribeiro. São Paulo: Martins Fontes, 2010.

IAVELBERG, R. Desenho na Educação Infantil. São Paulo: Melhoramentos, 2013.

IAVELBERG, R. O desenho cultivado na criança: práticas e formação de educadores. Porto Alegre: Zouk, 2006.

JOBIM E SOUZA, S. Mikhail Bakhtin e as ciências humanas: sobre o ato de pesquisar. In: FREITAS, M. T. A. (Org.). Escola, tecnologias digitais e cinema. Juiz de Fora/MG: Editora da UFJF. p. 35-44.

MCCARTY, P. Jeremias desenha um monstro. Tradução de Rosemarie Ziegelmaier. São Paulo: Globinho, 2012.

Olhar de professor, Ponta Grossa, v. 24, p. I-25, e- 17561.074, 202 I.

Disponível em <https://revistas2.uepg.br/index.php/olhardeprofessor> 
MERLEAU-PONTY, M. Fenomenologia da Percepção. Tradução de Carlos Alberto Ribeiro de Moura. São Paulo: Martins Fontes, 1999.

PILLAR, A. D. Desenho e construção do conhecimento na infância. Porto Alegre: Artes Médicas, 1996.

PILLAR, A. D. Desenho e escrita como sistema de representação. Porto Alegre: Penso, 2012.

PILLAR, A. D. Leitura e releitura. In: PILLAR, A. D. (Org.), A educação do olhar no ensino das artes. $8^{\mathrm{a}}$ ed. Porto Alegre: Editora Mediação, 2014. p. 7-I7.

DIAS DE PONTES, G. M.; PILLAR, A. D. Experiência estética na semiótica discursiva: pistas para leitura de textos de professores sobre suas práticas. Palíndromo, Florianópolis, v. I0, n. 22, p. 12 24, 20 I8. https://doi.org/I0.5965/2I752346/022020I80I2.

POSTHUMA, S. O Arame de Alexandre. Tradução de Lucas Simone: São Paulo: Editora 34, 2015.

ZABALA, A. A prática educativa: como ensinar. Porto Alegre: Artmed, 1998.

Recebido em: 16 de março de 2021.

Versão corrigida recebida em: 07 de junho de 202I.

Aceito em: 08 de junho de 2021.

Publicado online em: 23 de julho de 2021 .

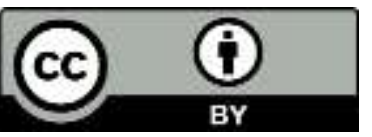

